\title{
Respiratory Characteristics of Neonatal Rat Hepatocytes
}

\author{
TAK YEE AW AND DEAN P. JONES \\ Department of Biochemistry, Emory University School of Medicine, Atlanta, Georgia 30322
}

\begin{abstract}
Mitochondrial function was studied in isolated hepatocytes from newborn rats to determine the substrate requirements and oxygen dependence of perinatal respiratory activity. The results show that neonatal $\mathrm{O}_{2}$ consumption is markedly dependent on succinate availability; the respiration rate was extremely low in the absence of exogenous substrates, but was stimulated 15-fold by succinate, with half-maximal stimulation of $\mathrm{O}_{2}$ consumption at $0.5 \mathrm{mM}$ succinate. Significant inhibition of respiration by low concentrations of antimycin $A$ suggests that the succinate-induced increase in cellular $\mathrm{O}_{2}$ consumption was primarily due to mitochondrial activity. In contrast, other potential metabolic fuels at comparable concentrations ( 2.5 to $10 \mathrm{mM}$ ) gave less than 2-fold stimulation. Half-maximal oxidation ( $P_{50}$ value) of the mitochondrial cytochromes occurred at very low $\mathrm{O}_{2}$ concentrations and was sensitive to factors that alter cellular $\mathrm{O}_{2}$ consumption. The $P_{50}$ for cytochrome $c$ oxidation $(0.52 \mu \mathrm{M}$ with $1.5 \mathrm{mM}$ succinate) was, respectively, increased or decreased by additions of succinate or antimycin $\mathbf{A}$. These distinctly lower $\mathbf{P}_{50}$ values for mitochondrial function in neonatal cells compared to adult cells could be a major factor in the ability of fetal and neonatal cells to tolerate relatively low $\mathrm{O}_{2}$ concentrations. (Pediatr Res 21: 492-496, 1987)
\end{abstract}

\begin{abstract}
Abbreviations
HPLC, high performance liquid chromatography

FCCP, carbonylcyanide-p-trifluoromethoxyphenyl hydrazone

$\mathbf{P}_{50}$, half-maximal oxidation
\end{abstract}

The transition from fetus to neonate involves a shift from a relatively anaerobic environment to an aerobic one and is associated with a marked change in content of enzymes of the respiratory systems (1-4). Central to the ability of the neonate to accommodate increased oxidative activity during this period is the attainment of functional maturity of mitochondrial activity. Currently, there is a lack of an understanding of the biochemical changes in mitochondrial function accompanying perinatal $\mathrm{O}_{2}$ variations, and given the association of hypoxia and hyperoxia with various pathological processes in the neonate [e.g. infant respiratory distress syndrome (5), sudden infant death syndrome (6), and fetal alcohol syndrome (7)], it is crucial to define the factors that determine respiratory function and control in this critical period.

In earlier studies of cells from various adult tissues, we found that both substrate supply and $\mathrm{O}_{2}$ dependence of the mitochon-

Received September 8, 1986; accepted December 16, 1986.

Correspondence and reprint requests to Dr. Tak Yee Aw, Department of Biochemistry, Emory University School of Medicine, Atlanta, GA 30322.

Supported by NIH Grants HL 30286 and GM 36538. drial respiratory system limit cell function at $\mathrm{O}_{2}$ concentrations that can occur in vivo during hypoxia (8-11). Similar studies to define the effect of substrates and $\mathrm{O}_{2}$ on function of the neonatal mitochondria under varied $\mathrm{O}_{2}$ concentrations have not been performed. In the current study, we characterize the effect of these parameters on perinatal respiratory function in cells freshly isolated from neonatal rat liver. This approach relies on the availability of isolation procedures for viable hepatocytes from rat fetuses and neonates with high yields that are essentially free from contamination by other cell types (12-14). Such preparations have been characterized with regard to numerous cell functions, viz, retention of cytoplasmic enzymes and metabolites (12), hormone sensitivity (13), and the ability to synthesize $\alpha$ fetoprotein (14), and therefore provide a means to obtain sufficient quantities of cells that are suitable for studies of cellular respiration.

We have examined the respiratory features of hepatocytes from newborn rats based on our earlier studies with adult cells which included measures of $\mathrm{O}_{2}$ consumption rates, ATP content, substrate requirements, and oxidation-reduction states of mitochondrial cytochromes $(5-8,15)$. The results show that neonatal hepatocellular respiration rates are responsive selectively to succinate and that mitochondrial respiration is maximal at a substantially lower $\mathrm{O}_{2}$ concentration than found in adult liver cells. The remarkable sensitivity to succinate suggests that these neonatal cells have a unique metabolic substrate demand and may therefore be sensitive to control by mechanisms in a manner which is at least quantitatively distinct from that found in adult tissues.

\section{MATERIALS AND METHODS}

Cell isolation. Rats (10-15 pups, 22 days at term) were delivered by natural birth and removed from their mothers (SpragueDawley female rats, $250 \mathrm{~g}$ from Animal King Laboratories, Oregon, WI) within $12 \mathrm{~h}$ of birth. Newborn rats were sacrificed by decapitation, and livers were quickly removed, weighed, sliced, and washed free of excess blood with $\mathrm{Ca}^{2+}$-free Hanks buffer, $\mathrm{pH}$ 7.4. Hepatocytes were isolated according to a minor modification of the method of Devirgiliis et al. (12). Briefly, sliced liver tissues were incubated with collagenase $(1 \mathrm{mg} / \mathrm{ml})$ and DNase $(0.05 \mathrm{mg} / \mathrm{ml})$ at $37^{\circ} \mathrm{C}$ under a $95 \% \mathrm{O}_{2}, 5 \% \mathrm{CO}_{2}$ atmosphere for successive 15 -min incubations with three changes of fresh digestion medium. Cells were filtered through nylon sizing mesh (mesh size 103), washed with modified Krebs-Henseleit medium, $\mathrm{pH} 7.4(15,16)$, and then purified on $30 \%$ Percoll in Krebs-Henseleit. Hepatocytes were assessed for viability by their ability to exclude $0.2 \%$ trypan blue and for contamination by erythrocytes and hematopoietic cells by morphological differences in appearance under a light microscope. The cells were maintained at $20^{\circ} \mathrm{C}$ in a gyrating water bath for 5-6 h without loss of viability.

Incubations and measurements of $\mathrm{O}_{2}$ consumption. Incubations $\left(1 \times 10^{6}\right.$ cells $\left./ \mathrm{ml}\right)$ were carried out at $37^{\circ} \mathrm{C}$ in rotating 
round bottom flasks in modified Krebs-Henseleit buffer containing $25 \mathrm{mM}$ Hepes, $\mathrm{pH} 7.4$, as previously described $(15,16)$. After 30-min preincubation, samples were removed for ATP determination and measurements of $\mathrm{O}_{2}$ consumption. Cellular $\mathrm{O}_{2}$ consumption rates in the absence or presence of substrates and inhibitors were measured polarographically with a Clark-type electrode (17).

Spectrophotometry. Oxidation-reduction changes of mitochondrial cytochromes were determined by dual-wavelength spectrophotometry on an Aminco DW2a spectrophotometer equipped with a $3.9-\mathrm{cm}$ light path incubation vessel $(18,19)$. Cells were maintained in suspension by gentle stirring with a magnetic stirrer, and $\mathrm{O}_{2}$ concentrations were measured by an $\mathrm{O}_{2}$ electrode inserted through the cover of the incubation vessel. The gaseous phase was flushed continuously with prepurified argon $(<0.001 \%$ $\mathrm{O}_{2}$ ) delivered via a low $\mathrm{O}_{2}$-permeability butyl rubber tubing. Oxidation-reduction changes for the cytochromes and pyridine nucleotides were measured with the following wavelength pairs (nm): cytochrome $a+a_{3}, 605-630$; cytochrome $c+c_{1}, 550-540$; cytochrome $b_{561}+b_{566}, 561-575$; cytochrome $b_{566}, 566-575$; and pyridine nucleotide, $340-375$. The mitochondrial cytochrome contents were calculated from the absorbance changes following reduction of the oxidized forms with dithionite as well as from the changes following aerobic to anaerobic transitions, and using the respective millimolar extinction coefficients $\left(\mathrm{mM}^{-1} \mathrm{~cm}^{-1}\right)$ of the wavelength pairs as indicated above for cytochromes $a+a_{3}$, $13.1 ; c+c_{1}, 19 ;$ and $b, 23(20-23)$.

Assays. Perchloric acid extracts of cell incubations were neutralized with $10 \mathrm{M} \mathrm{KOH}$ and the supernatants were analyzed for ATP by HPLC (24). Total cell protein contents were determined on the acid precipitable fractions by the method of Bradford (25) using the protein dye-reagent concentration from Biorad and bovine $\gamma$-globulins as standard.

Materials. The following chemicals were purchased from Sigma Chemical Co. St. Louis, MO: collagenase type IV, deoxyribonuclease (DNAse) I, $\gamma$-globulin, (bovine, Cohn Fraction II), $\mathrm{N}$-2-hydroxyethylpiperazine- $\mathrm{N}^{\prime}$-2-ethanesulfonic acid (Hepes), glucose, fructose, L-glutamate, L-aspartate, acetoacetate, malate, citrate, lactate, $\beta$-hydroxybutyrate, 2-oxoglutarate, acetate, oleic acid, and antimycin A. Sodium succinate was obtained from Eastman Kodak Co., Rochester, NY, sodium butyrate from Matheson Coleman and Bell, East Rutherford, NJ and FCCP from Boehringer-Mannheim, Mannheim, West Germany. Other chemicals were of reagent grade and were purchased from local sources.

\section{RESULTS}

Characteristics of neonatal hepatocytes. The current study is designed to examine the substrate and $\mathrm{O}_{2}$ requirements for mitochondrial function in neonatal cells. Studies were performed using freshly isolated hepatocytes from newborn rats, and initial characterization of the cells are summarized in Table 1. Cell yields, percent viable cells, and protein contents were comparable to preparations of fetal and neonatal hepatocytes reported by others (12-14). Respiration rates were extremely low in the absence of added substrates $\left(0.49 \pm 0.05 \mathrm{nmol} \mathrm{O} 2 / 10^{6}\right.$ cells per min) but were stimulated 15 -fold in the presence of $5 \mathrm{mM}$ succinate (see below). The increase in $\mathrm{O}_{2}$ consumption was not further stimulated by addition of $0.2 \mathrm{mM}$ ADP, indicating that the cells retain their permeability barrier to intermediate molecular weight compounds. Cellular ATP content was one-third that of adult cells when expressed per mg protein $(15,17)$ and was increased slightly in the presence of succinate. The contents of mitochondrial cytochromes were about half that found in adult cells when expressed per $10^{6}$ cells, although they were in the same relative proportions $(17,23)$; notably, cytochrome $a+a_{3}$ and $c+c_{1}$ were twice that of the $b$ cytochromes (Table 1). The cellular $\mathrm{O}_{2}$ consumption rates and cytochrome contents were $20-40 \%$ lower than adult values even when these were expressed
Table 1. Characteristics of isolated hepatocytes from newborn rats; cell isolation and incubations were as described in text*

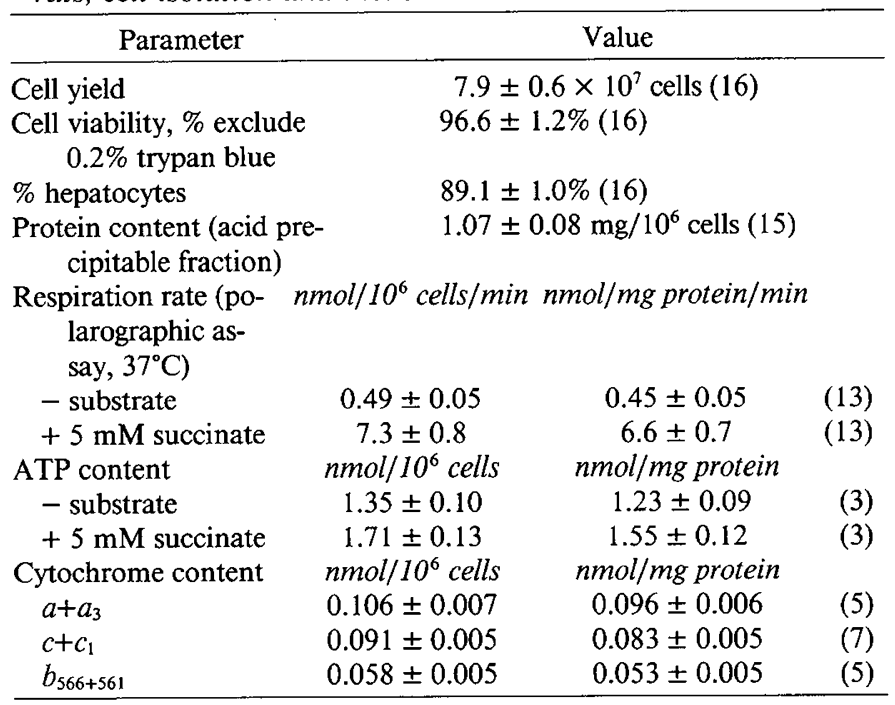

${ }^{*} \mathrm{O}_{2}$ consumption was measured polarographically with an $\mathrm{O}_{2}$ electrode, and cell ATP contents were measured by HPLC (24). Mitochondrial cytochrome contents were calculated from the absorbance change upon reduction of the cytochromes and the respective millimolar extinction coefficients (see "Materials and methods"). Values given are the mean \pm SEM for the number of cell preparations in parentheses. Livers from 10-15 pups were pooled for one cell preparation.

on a per mg protein basis (Table 1). The results therefore indicate that the respiratory characteristics of neonatal hepatocytes are quantitatively distinct from adult cells.

Effects of substrates on respiration. The low cellular $\mathrm{O}_{2}$ consumption rates with endogenous substrates (Table 1) suggest the possibility of a requirement for an exogenous substrate supply. To test this, we examined the effect of several citric acid cycle and glycolytic intermediates, ketone bodies, fatty acids, and amino acids on $\mathrm{O}_{2}$ consumption. The results (Table 2 ) show that ketone bodies ( $\beta$-hydroxybutyrate and acetoacetate), butyrate, and amino acids (glutamate and aspartate) were ineffective in eliciting an increase in $\mathrm{O}_{2}$ consumption while oleate and many of the citric acid cycle and glycolytic substrates (fructose, malate, lactate, and 2-oxoglutarate) gave 1.3- to 1.6-fold enhancements in rates. In marked contrast, succinate exhibited an approximately 15 -fold stimulation of respiration rate, while similar studies with adult hepatocytes consistently showed less than a 2fold increase in $\mathrm{O}_{2}$ consumption (data not shown). These results suggest that succinate is a preferred and selective substrate for cellular respiration in neonatal cells.

Other studies with respiratory inhibitors showed that the increase in $\mathrm{O}_{2}$ consumption in the presence of succinate is predominantly due to mitochondrial respiration; low concentrations of antimycin $\mathrm{A}(16-32 \mathrm{nM})$ inhibited the succinate-induced respiration by $95 \%$. However, addition of $1 \mu \mathrm{M}$ FCCP, a protonophore, in the presence of succinate gave no further stimulation of $\mathrm{O}_{2}$ consumption, indicating that maximal stimulation of rate had occurred with succinate alone. Moreover, the succinateinduced increase in $\mathrm{O}_{2}$ consumption was inhibited by malonate and oxaloacetate, which indicates that succinate is oxidized by succinate dehydrogenase. Fumarate has also been identified by HPLC separation as a major product (data not shown).

The responsiveness of mitochondrial respiration to succinate was defined by examination of the dose-dependent relationship of $\mathrm{O}_{2}$ consumption and and succinate concentration. The results showed that stimulation of cellular respiration rates occurred over a wide range of succinate concentrations (30 $\mu \mathrm{M}$ to 8.5 $\mathrm{mM}$, Fig. 1), with maximal and half-maximal rates occurring at 5 and $0.5 \mathrm{mM}$, respectively (Fig. 1). The maximally stimulated rate, as predicted from the cytochrome contents of the cells 
Table 2. Effect of substrates on respiration rates in neonatal hepatocytes*

\begin{tabular}{lcc}
\hline \multicolumn{1}{c}{ Substrate } & $\begin{array}{c}\text { Ratio of } \\
\text { Concentration } \\
(\mathrm{mM})\end{array}$ & $\begin{array}{c}\text { respiration rates } \\
\text { + substrate/ } \\
\text { - substrate }\end{array}$ \\
\hline $\begin{array}{l}\text { Glycolytic and citric } \\
\text { acid cycle sub- }\end{array}$ & & \\
strates & & \\
Glucose & 10 & $1.2 \pm 0.1(3)$ \\
Fructose & 10 & $1.3 \pm 0.2(3)$ \\
Citrate & 5 & $1.2 \pm 0.1(5)$ \\
2-oxoglutarate & 5 & $1.3 \pm 0.1(6)$ \\
Pyruvate & 5 & $1.1 \pm 0.1(6)$ \\
Malate & 5 & $1.4 \pm 0.1(6)$ \\
Acetate & 5 & $1.2 \pm 0.1(4)$ \\
Lactate & 10 & $1.6 \pm 0.2(7)$ \\
Succinate & 5 & $1.1 \pm 0.7(11)$ \\
Ketone bodies & & $1.2 \pm 0.3(4)$ \\
$\beta$-OH butyrate & 2.5 & $1.1 \pm 0.1(6)$ \\
Acetoacetate & 2.5 & $1.1 \pm 0.1(4)$ \\
Amino acids & & $1.2 \pm 0.1(6)$ \\
Glutamate & 5 & $1.3 \pm 0.1(5)$ \\
Aspartate & 5 & \\
Fatty acid & 2.5 & \\
Butyrate (4:0) & 2.5 & \\
Oleate (18:1) & &
\end{tabular}

* Cellular $\mathrm{O}_{2}$ consumption rates were measured as described in "Materials and methods." Substrates were added in small volumes to the cell suspension to the indicated final concentrations. Values are given as the ratio of rates in the presence and absence of substrates (see Table 1) and are the mean \pm SEM of the number of cell preparations in parentheses. Livers from 10-15 pups were pooled for one cell preparation.

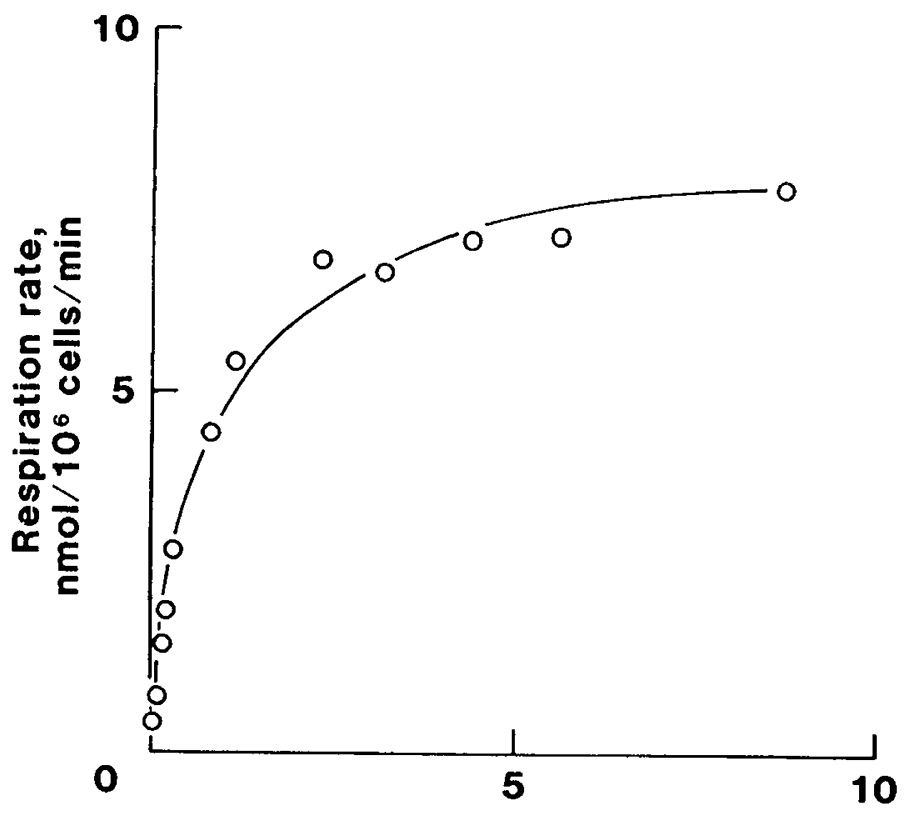

\section{Succinate, $\mathrm{mM}$}

Fig. 1. Dependence of $\mathrm{O}_{2}$ consumption rate on succinate concentration. Cellular respiration rates were determined in incubations $\left(1 \times 10^{6}\right.$ cells/ml) containing different concentrations of succinate ranging from 0.03 to $8.5 \mathrm{mM} . \mathrm{O}_{2}$ consumption was measured polarographically with an $\mathrm{O}_{2}$ electrode.
(Table 1), was about one-half that of adult cells. This sensitivity of $\mathrm{O}_{2}$ consumption to succinate suggests that circulating plasma succinate $(50 \mu \mathrm{M})$ may be a respiratory substrate and/or a specific stimulator of respiration of neonatal hepatocytes (see "Discussion").

Oxidation-reduction of mitochondrial cytochromes. Earlier studies with adult hepatocytes showed that the $\mathrm{O}_{2}$ concentration required for maximal respiration is a function of the $\mathrm{O}_{2}$ consumption rate (19). Since the endogenous $\mathrm{O}_{2}$ consumption in these neonatal cells is very low, the $\mathrm{O}_{2}$ requirement for maximal mitochondrial function in neonatal cells may also be small. To examine this, we determined the mitochondrial $\mathrm{O}_{2}$ dependence by the oxidation-reduction changes of the cytochromes. $P_{50}$ values for the different cytochromes was measured in the presence of $1.5 \mathrm{mM}$ succinate, and the results (Table 3 ) showed that the values were extremely low $(<1 \mu \mathrm{M})$, in a range that is similar to that found for isolated mitochondria.

It is significant that the $P_{50}$ values for neonatal hepatocytes are substantially lower than the values for adult hepatocytes. Previous studies showed that the high $\mathrm{P}_{50}$ values in adult hepatocytes is a consequence of the clustering of mitochondria within the cells $(27,28)$ which increases the extracellular $\mathrm{O}_{2}$ concentration required to maximally oxygenate all of the mitochondria. The relatively low $\mathrm{P}_{50}$ values for oxidation of mitochondrial cytochromes in neonatal cells are consistent with the interpretation that mitochondria are present at a lower density (indicated by the cytochrome measurements above) and not extensively clustered [see electron micrographs of Devirgiliis et al. (12)]. Therefore, the results suggest that an important developmental change from fetal cells to adult cells involves enzymatic and structural changes that increase functional capacity and concomitantly increase the $\mathrm{O}_{2}$ concentrations required for optimal function.

Direct comparison of the $\mathrm{P}_{50}$ values further shows that they are essentially the same for all the cytochromes, i.e. between 0.5 and $0.75 \mu \mathrm{M}$ (Table 3). Thus, the entire electron transport chain functions as a single unit, as with adult hepatocytes (19). Because the $\mathrm{O}_{2}$ consumption is mostly succinate dependent, a kinetic limitation at the NADH dehydrogenase could result in a different $\mathrm{O}_{2}$ dependence for the pyridine nucleotides. However, the $\mathrm{P}_{50}$ value for oxidation of pyridine nucleotides was comparable to that for the cytochromes (Table 3 ). Therefore, the relatively minor stimulation of respiration by the other citric acid cycle intermediates (Table 2) may not be due simply to rate limitation by NADH dehydrogenase.

The sensitive response of cellular respiration rate to succinate availability suggests that the function of the neonatal mitochondria would selectively vary with substrate supply and $\mathrm{O}_{2}$ consumption rate. This possibility was examined by measuring $P_{50}$ of cytochrome $c+c_{1}$ in cell incubations containing varied concentrations of succinate and/or antimycin A. For these studies, the temperature of the cell suspensions was maintained between 25 and $28^{\circ} \mathrm{C}$ because of the construction of the incubation vessel, and this resulted in a lower respiration rate of the

Table 3. $P_{50}$ values of mitochondrial cytochromes and pyridine nucleotides in neonatal hepatocytes*

\begin{tabular}{cc}
\hline Parameter & $\mathrm{P}_{50}\left(\mu \mathrm{M} \mathrm{O}_{2}\right)$ \\
\hline Cytochromes & \\
$a+a_{3}$ & $0.68 \pm 0.08(5)$ \\
$c+c_{1}$ & $0.53 \pm 0.07(7)$ \\
$b_{561+566}$ & $0.75 \pm 0.05(5)$ \\
Pyridine nucleotide & $0.52 \pm 0.06(4)$ \\
\hline
\end{tabular}

* The oxidation-reduction changes were measured spectrophotometrically with the following wavelength pairs $(\mathrm{nm})$ : for the cytochromes, $a+a_{3}, 605-630 ; c+c_{1}, 550-540 ; b_{561+566}, 561-575$; and for pyridine nucleotide, 340-375. Values given are the mean \pm SEM of the number of cell preparations in parentheses. 
cells compared to measurements at $37^{\circ} \mathrm{C}$. Additionally, the cells were also exposed to hypoxic/anoxic conditions which can further decrease maximal respiratory activity (10). Addition of 0.5 $\mathrm{mM}$ succinate to cell incubations under these conditions resulted in an $\mathrm{O}_{2}$ consumption rate of $0.98 \mathrm{nmol} / 10^{6}$ cell per min and a $\mathrm{P}_{50}$ value of $0.17 \mu \mathrm{M} \mathrm{O}_{2}$ (Fig. 2). Increasing the $\mathrm{O}_{2}$ consumption rate to $2.0 \mathrm{nmol} / 10^{6}$ cells per min with $3.3 \mathrm{mM}$ succinate increased the $\mathrm{P}_{50}$ value to $0.35 \mu \mathrm{M}$, while inhibiting respiration by antimycin $\mathrm{A}(5.6 \mathrm{nM})$ correspondingly decreased the $\mathrm{P}_{50}$ value to $0.035 \mu \mathrm{M} \mathrm{O}$ (Fig. 2). Consequently, the $\mathrm{O}_{2}$ concentration required for mitochondrial function in neonatal hepatocyte varies as a function of the substrate supply and $\mathrm{O}_{2}$ consumption rate.

\section{DISCUSSION}

The current study demonstrates that the mitochondrial function of neonatal hepatocytes can be readily altered by addition of substrate and respiratory inhibitors. The respiratory characteristics of these cells differ from adult hepatocytes $(16,17,19)$ in two important respects, namely, the stimulation by succinate is unique and the magnitude of this stimulation is relatively large. In adult cells, respiration with endogenous substrates is about 8 $12 \mathrm{nmol} \mathrm{O}_{2} / \mathrm{mg}$ protein per min $(17,29,30)$. Addition of various substrates typically gives less than a 2-fold stimulation, and even cells from $48 \mathrm{~h}$ starved animals show only about 2.2-fold stimulation (31). Of note, succinate $(2 \mathrm{mM})$ gives approximately a $25 \%$ stimulation of respiration (32). Thus, the dramatic stimulation by succinate in neonatal hepatocytes is different than the response in adult cells.

When expressed relative to cytochrome oxidase content (taken as one-half cytochrome $a+a_{3}$ ), the $\mathrm{O}_{2}$ consumption is about 3 nmol $\mathrm{O}_{2}$ consumed/nmol oxidase per $\mathrm{s}$ for adult cells (33). Calculation of the turnover number for cytochrome oxidase in neonatal cells in the presence of $5 \mathrm{mM}$ succinate (Table 1) yields a value of $2.2 \mathrm{nmol} \mathrm{O} / \mathrm{nmol}$ oxidase per s. Thus, even under the maximally stimulated state with succinate, the respiratory activity of neonatal hepatocytes is lower compared to adult cells. This indicates that neonatal cells are highly dependent on a continuous supply of exogenous nutrients.

The mechanism of stimulation of $\mathrm{O}_{2}$ consumption by succinate is not clear at present but may reflect the developmentally regulated differences in isozymic forms of respiratory enzymes (4) or differences in rates of uptake of succinate and other substrates. Succinate appears to be functioning as a direct substrate for the mitochondria because fumarate is formed and

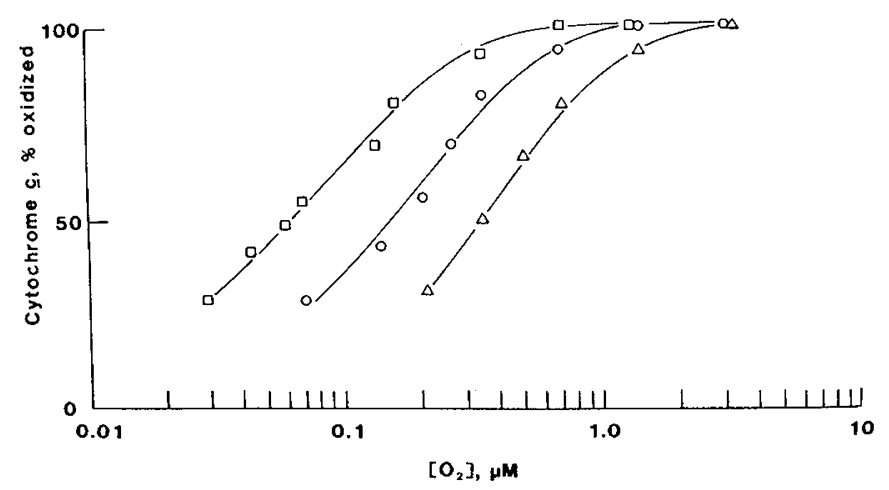

Fig. 2. $\mathrm{O}_{2}$ dependence of cytochrome $\mathrm{c}$ oxidation in the presence of succinate and antimycin $\mathrm{A}$. The $\mathrm{O}_{2}$ dependence of oxidation-reduction changes in cytochrome $c$ was determined in incubations $\left(1.5 \times 10^{6}\right.$ cells/ ml) containing $0.5 \mathrm{mM}$ succinate $(O), 3.3 \mathrm{mM}$ succinate $(\Delta)$ and 3.3 $\mathrm{mM}$ succinate plus $5.6 \mathrm{nM}$ antimycin $\mathrm{A}(\square)$. Changes were measured using the wavelength pair, $550-540 \mathrm{~nm}$. Results are expressed as \% oxidized calculated with respect to aerobic cells. could be a preferred substrate due to limitations in activities of $\mathrm{NAD}^{+}$-linked dehydrogenases. Alternatively, succinate may serve to prime the citric acid cycle. This may be necessary to allow efficient function of the cycle, as has been suggested for certain disease states (34). Succinate may also stimulate metabolism by shifting the succinate/succinyl-CoA ratio, which is known to be central to the regulation of the citric acid cycle (35). Finally, succinate may function as a metabolic regulator, perhaps mediated through succinyl-CoA, to shift metabolism to a more active state.

The succinate-dependent stimulation does not appear to be related to the stimulation of mitochondrial respiratory activity by increased adenine nucleotide pool size (36-38) because the time courses for the two processes are different. Dramatic increases in the mitochondrial adenine nucleotide pool occur within hours after birth while the succinate effect persists for several days (data not shown). Furthermore, the results with the FCCP studies support this interpretation since further stimulation of $\mathrm{O}_{2}$ consumption would be expected if adenine nucleotides were limiting. Also, it does not appear likely that the succinate effect is related to increased heme biosynthesis (which requires succinyl-CoA) because the total heme pool in the cells studied is already about one-third to one-half of that in the adult cells. However, this possibility, as well as those listed above, must be further investigated.

The physiological significance of the succinate effect is not entirely clear at present. While the adult plasma succinate concentration $(50 \mu \mathrm{M})$ is lower than that required for one-half maximum respiration in neonatal cells, the plasma concentration of succinate in the fetus and newborn could be higher. Since the mitochondria maintain a 5-fold higher succinate concentration in the matrix, a similar concentrative uptake system for succinate at the plasma membrane in neonatal cells could increase succinate levels several fold, in the range of $200-300 \mu \mathrm{M}$. This would correspond to a 4- to 5-fold stimulation of cellular respiration and thus could be physiologically significant in increasing the oxidative capacity of neonatal cells. We found that the succinateinduced stimulation of $\mathrm{O}_{2}$ consumption in neonatal hepatocytes decreases with increasing age of the rats (data not shown) which may correspond to a developmental change in the ability of the cells to selectively utilize succinate.

Comparison of the $\mathrm{O}_{2}$ dependence of oxidation-reduction of mitochondrial cytochromes of neonatal hepatocytes with those of adult cells shows that the $\mathrm{P}_{50}$ values in neonatal cells are relatively low. The $\mathbf{P}_{50}$ value for cytochrome $c$ in adult cells is 6 $\mu \mathrm{M}(19,27)$, while that for isolated state 3 mitochondria from adult rat liver is about $0.6 \mu \mathrm{M}$ (27). The oxygen dependence of neonatal cells is therefore closer to that of isolated mitochondria than that of adult cells. We previously found that in adult hepatocytes, the spatial distribution of mitochondria largely determines the magnitude of $\mathrm{O}_{2}$ gradients within liver cells (19, 27). Thus, mitochondrial clustering decreases $\mathrm{O}_{2}$ availability for mitochondrial function and accounts for the higher $P_{50}$ values for oxidation of the cytochromes in cells compared to that in isolated mitochondria (28). The mitochondrial density in the neonatal cells seems to be low, as indicated by the cytochrome contents. Moreover, examination of electron micrographs of fetal and neonatal hepatocytes reveals the presence of a small number of mitochondria that appear to be distributed randomly throughout the cytoplasm of the cells (12). This apparent lack of mitochondrial clusters in fetal and neonatal hepatocytes would impose minimal limitation in $\mathrm{O}_{2}$ supply to the mitochondria and thus could explain the lower measured $\mathrm{P}_{50}$ values.

The low $\mathrm{P}_{50}$ values for mitochondrial function could be an important factor in the ability of fetal and neonatal cells to tolerate low $\mathrm{O}_{2}$ concentrations since the physiological arterial $\mathrm{pO}_{2}$ in the fetus, $25-30$ torr $\left(30-35 \mu \mathrm{M} \mathrm{O}_{2}\right)$, is substantially lower than in the adult. Because the operative $\mathrm{pO}_{2}$ in venous blood, which predominantly supplies the liver in the fetus, can be 
considerably lower $\left(10-15 \mu \mathrm{M} \mathrm{O}_{2}\right)$, the $\mathrm{pO}_{2}$ to which fetal cells are exposed is lower than the adult. Thus, to maintain maximal $\mathrm{O}_{2}$ consumption rates, the fetal $\mathrm{P}_{50}$ values must be significantly lower than the adult values. Because the neonatal period is a transition from fetal to adult, the respiratory characteristics of neonatal cells will reflect, in part, that of fetal cells, as have been found in the current study.

The correspondence of the $\mathrm{P}_{50}$ values for the different cytochromes in the neonatal cells suggests that the mitochondrial electron transport proteins respond to variations in $\mathrm{O}_{2}$ concentrations as a single unit. The same relative amounts of these cytochromes in neonatal cells as found in adult cells (23) implies that expression of these respiratory components occurs in concert during development even though the appearance of many enzyme and cytochrome systems in fetal mitochondria does not appear to be synchronized (4).

In summary, these studies with freshly isolated hepatocytes from neonatal rats show that respiration is highly dependent on succinate and sensitive to $\mathrm{O}_{2}$ concentration only at very low values. The difference in respiratory characteristics compared to those of adult cells may be the result of differences during development in activities of transport and respiratory enzymes, structure and distribution of mitochondria, and control of respiratory functions.

\section{REFERENCES}

1. Van Rossum GDV 1963 Respiration and glycolysis in liver slices prepared from rats of different foetal and post-natal ages. Biochim Biophys Acta 74:15-23

2. Jakovcic S, Haddock J, Getz GS, Rabinowitz M, Swift H 1971 Mitochondrial development in liver of foetal and newborn rats. Biochem J 121:341-347

3. Pollak JK, Duck-Chong CG 1973 Changes in rat liver mitochondria and endoplasmic reticulum during development and differentiation. Enzyme 15:139-160

4. Jones CT 1982 The development of the metabolism in the fetal liver. In: Jones CT (ed) Biochemical Development of the Fetus and Neonate. Elsevier Biomedical Press, Amsterdam, pp 249-286

5. Frank L 1985 Effects of oxygen on the newborn. Fed Proc 44:2328-2334

6. Naeye RL 1980 Sudden infant death. Sci Am 242:56-62

7. Abel EL 1982 Consumption of alcohol during pregnancy: a review of effects on growth and development of offspring. Hum Biol 54:421-453

8. Aw TY, Jones DP 1984 Control of glucuronidation during hypoxia: limitation by UDP-glucose pyrophosphorylase. Biochem J 219:707-712

9. Aw TY, Jones DP 1985 ATP concentration gradients in cytosol of liver cells during hypoxia. Am J Physiol 249:C385-C392

10. Jones DP, Kennedy FG, Andersson BS, Aw TY, Wilson E 1985 When is a mammalian cell hypoxic? Insights from studies of cells $y s$ mitochondria. Mol Physiol 8:473-482

11. Kennedy FG, Jones DP 1986 Oxygen dependence of mitochondrial function in isolated rat cardiac myocytes. Am J Physiol 250:C374-C383

12. Devirgiliis LC, Dini L, DiPierro A, Leoni S, Spagnuolo S, Stefanini S 1981 An improved nonperfusion method for the isolation and purification of rat foetal and neonatal hepatocytes. Cell Mol Biol 27:687-694

13. De Sante DC, Little L, Peavy DE, Vinicor F 1984 Insulin-responsive cultured foetal-rat hepatocytes. Biochem J 223:39-46
14. Radford J, Bhathal PS 1985 Purification of fetal rat hepatocytes. Cell Biol Int Rep 9:677-688

15. Aw TY, Jones DP 1982 Secondary bioenergetic hypoxia. Inhibition of sulfation and glucuronidation reactions in isolated hepatocytes at low $\mathrm{O}_{2}$ concentration. J Biol Chem 257:8997-9004

16. Moldeus $P$, Hogberg $J$, Orrenius S 1978 Isolation and use of liver cells. Methods Enzymol 51:60-70

17. Jones DP, Mason HS 1978 Gradients of $\mathrm{O}_{2}$ concentration in hepatocytes. J Biol Chem 253:4874-4880

18. Jones DP, Thor H, Andersson BS, Orrenius S 1978 Detoxification reaction in isolated hepatocytes. Role of glutathione peroxidase, catalase, and formaldehyde dehydrogenase in reactions relating to $N$-demethylation by the cytochrome P-450 system. J Biol Chem 253:6031-6037

19. Jones DP, Kennedy FG 1982 Intracellular oxygen supply during hypoxia. Am J Physiol 243:C247-C253

20. Chance B, Hagihara B 1963 Direct spectroscopic measurements of interaction of components of the respiratory chain with ATP, ADP, phosphate, and uncoupling agents. Proc Int Congr Biochem 5:3-33

21. Omura T, Sato R 1964 The carbon monoxide-binding pigment of liver microsomes. J Biol Chem 239:2370-2378

22. Vanneste WH 1966 Molecular proportion of the fixed cytochrome components of the respiratory chain of Keilin-Hartree particles and beef heart mitochondria. Biochim Biophys Acta 113:175-178

23. Jones DP, Orrenius S, Mason HS 1979 Hemoprotein quantitation in isolated hepatocytes. Biochim Biophys Acta 576:17-29

24. Jones DP 1981 Determination of pyridine nucleotides in cell extracts by highperformance liquid chromatography. J Chromatogr 225:446-449

25. Bradford MM 1976 A rapid and sensitive method for the quantitation of microgram quantities of protein utilizing the principle of protein-dye binding. Anal Biochem 72:248-254

26. Krebs HA 1950 Chemical composition of blood plasma and serum. Ann Rev Biochem 19:407-430

27. Jones DP 1984 Effect of mitochondrial clustering on $\mathrm{O}_{2}$ supply in hepatocytes. Am J Physiol 247:C83-C89

28. Jones DP 1986 Intracellular diffusion gradients of $\mathrm{O}_{2}$ and ATP. Am J Physiol 250:C663-C675

29. Howard RB, Pesch LA 1968 Respiratory activity of intact, isolated parenchymal cells from rat liver. J Biol Chem 243:3105-3109

30. Quistorff B, Bondesen S, Grunnett N 1973 Preparation and biochemical characterization of parenchymal cells from rat liver. Biochim Biophys Acta 320:503-516

31. Krebs HA, Cornell NW, Lund P, Hems R 1974 Isolated liver cells as experimental material. In: Lundquist F, Tygstrup N (eds) Regulation of Hepatic Metabolism. Academic Press, New York, pp 726-750

32. Moldeus P, Grudin R, Vadi H, Orrenius S 1974 Study of drug metabolism linked to cytochrome P-450 in isolated rat liver cells. Eur J Biochem 46:351linke 360

33. Jones DP, Grafstrom R, Orrenius S 1980 Quantitation of hemoproteins in rat small intestinal mucosa with identification of mitochondrial cytochrome $\mathrm{P}$ 450. J Biol Chem 255:2383-2390

34. Reinke LA, Belinsky SA, Kauffman FC, Evans RK, Thurman G 1982 Regulation of NADPH-dependent mixed-function oxidation in perfused livers. Comparative studies with sorbitol and ethanol. Biochem Pharmacol $31: 1621-1628$

35. Williamson JR, Cooper RH 1980 Regulation of citric acid cycle in mammalian systems. FEBS Lett 117 (suppl):K73-K85

36. Aprille JR, Asimakis GK 1980 Postnatal development of rat liver mitochondria: state 3 respiration, adenine nucleotide translocase activity, and the net accumulation of adenine nucleotides. Arch Biochem Biophys 201:564-575

37. Aprille JR 1981 Net uptake of adenine nucleotides by newborn rat liver mitochondria. Arch Biochem Biophys 207:157-164

38. Rulfs J, Aprille JR 1982 Adenine nucleotide pool size, adenine nucleotide translocase activity and respiratory activity in newborn rabbit liver mitochondria. Biochim Biophys Acta 681:300-304 